\author{
Anna Blajer-Gołębiewska*, Arkadiusz Kozłowski**
}

\title{
Financial determinants of corporate reputation: A short-term approach
}

\section{Introduction}

When observing companies listed on stock exchanges, it can be noticed that the gap between a company's book value (BV) and its market value (MV) is often significant. The fact that investors are willing to pay more for companies' assets is often explained using the concept of corporate reputation - an intangible additional asset of a company, which is worth to paying for.

Similarly, analysing literature in the corporate reputation problem, its strong connection with the value of a company is often underlined; it is even claimed that corporate reputation represents the value of a company (Marcellis-Warin and Teodoresco, 2012, pp. 7-17). Corporate reputation is often defined as the perception of a company among its stakeholders, the outcome of shared socially impressions of a firm (Fombrun and Van Riel, 1997). It is a function of collective judgements of a firm 'based on assessments of the financial, social, and environmental impacts attributed to the corporation over time' (Barnett et al., 2006). There are many definitions of corporate reputation based mainly in economics, management, sociology, and psychology. There are also different determinants and aspects of corporate reputation that matter while taking into consideration each stakeholder group. Corporate reputation is fundamental for creating and establishing appropriate relationships between a company and its stakeholders.

It is widely claimed that a higher corporate reputation can encourage stakeholders to undertake certain activities that improve a company's financial situation in terms of profit, market value, etc. (Roberts and Dowling, 2002, pp. 1077-1093; Harrington, 2003, pp. 52-61; Riahi-Belkaoui, 2003, pp. 1-22; Cox et al., 2004, pp. 27-47; Anderson and Smith, 2006, pp. 86-93; Smith et al., 2010, pp. 201-221 etc.).

* University of Gdansk, Faculty of Economics, Microeconomics Department, e-mail: a.blajer@ug.edu.pl ** University of Gdansk, Faculty of Management, Statistics Department, e-mail: arkadiusz.kozlowski@ug.edu.pl 
On the one hand, a better financial situation results in an increase in a company's reputation (especially while approaching the problem from an investor's perspective); but on the other hand, a better corporate reputation is supposed to improve a company's performance. Fombrun (1996, p. 72) states that corporate reputation is "a perceptual representation of a company's past actions and future prospects...". Following this definition, Roberts and Dowling created a model of reputation-financial performance dynamics, where past financial performance influences reputation, and a reputation influences future financial performance of a given company (Roberts and Dowling, 2002, p. 1078; Figure 1).

Moreover, they indicate that investors do not have access to all of the information about a company, so their decisions rely mostly on 'previous financial performance outcomes as signals of a firm's overall esteem.' The authors decompose an overall reputation into a financial reputation (predicted by its previous financial performance) and residual reputation ('left over'; Fig. 1).

Studies on relationships between corporate reputation and its performance mostly consider the impact of corporate reputation on a company's performance; as a result, the aim of this study was to examine the other part of the Roberts and Dowling model of reputation-financial performance dynamics. Particularly, the aim of this study was to verify the short-term impact of financial variables on corporate reputation perceived by investors.

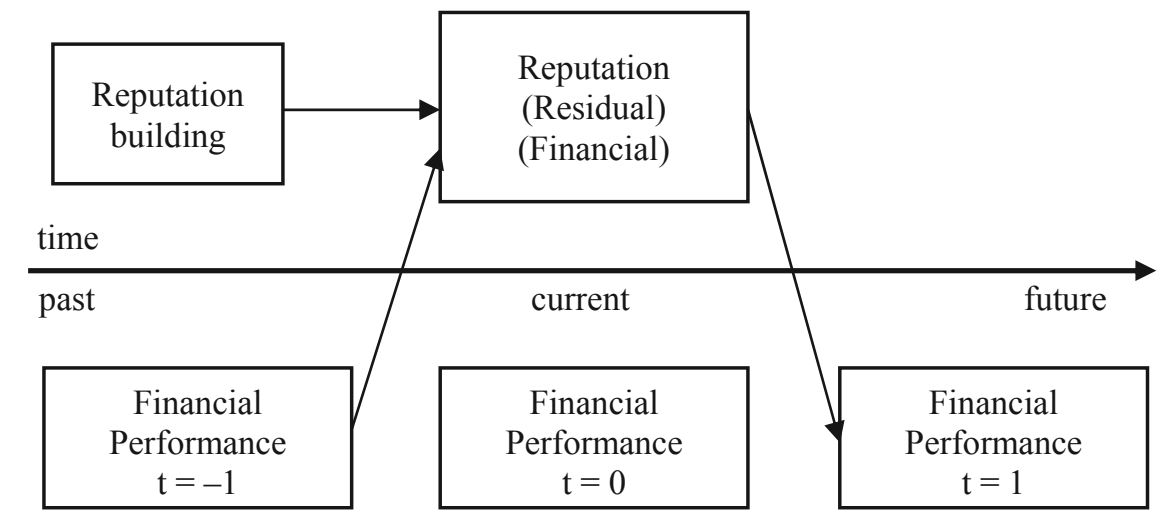

Figure 1. Roberts and Dowling's model of reputation-financial dynamics

Source: own compilation on the basis of Roberts and Dowling (2002, p. 1078)

In the study, we applied an assumption based on various business valuation theories and the literature in the subject, stating that overall corporate reputation 
is reflected in the difference between the valuation of a company by investors and its book value.

In order to verify their impact, financial variables were grouped into three categories measuring the level of a company's profitability, stability, and risk. This division aims to verify the most important financial characteristics for investors in the process of building their perception of a company's reputation, and later in influencing their behaviour on the stock exchange. The methods applied in the study are multiple regressions on ranks and on first differences and an analysis of contingency tables (chi-squared tests of independence and Yule's coefficient of colligation).

The article proceeds as follows. The next section provides a brief overview of the literature on previous studies on relationships between corporate reputation and companies' financial performances, as well as concepts of business valuation incorporating the idea of corporate reputation. In the following section, the applied methodologies are outlined. In the penultimate section, findings on the short-term determinants of corporate reputation are presented and discussed. The final section provides conclusions, the study weaknesses, and establishes directions for future research.

\section{Literature review}

As mentioned above, there is a wide array of studies on the impact of corporate reputation on a company's performance. According to Beatty and Ritter (1986, pp. 213-232) as well as Riahi-Belkaoui (1999, pp. 25-36), a better reputation can create a better image of a company in capital markets and a more-correct valuation by investors. In sociology and social psychology, an impression management theory suggests that the process of creating positive reputation leads to tangible benefits. This kind of management is a process in which one attempts to influence the perceptions of stakeholders about a company.

Some research also suggests that positive information (concerning reputation) is often overestimated, while negative information is either ignored or underestimated by stakeholders (Brennan et al., 2008, pp. 789-832). Positive financial information about a corporation's reputation increases the probability of buying its shares much more than positive information about corporate ethics (Blajer-Gołębiewska and Kos, 2016, pp. 11-31).

Moreover, corporate reputation may be relative. Roberts and Dowling (2002, pp. 1077-1093) suggest that a company's higher performance results from its advantages in its relationship with its competitors. Results of their study show that companies with superior reputations are better able to maintain superior profitability over time. Similar conclusions were drawn from the study of Smith 
and others. They compared high reputation firms to a control sample of firms and found that firms with high reputations receive a market value premium (\$1.3 billion on average; Smith et al., 2010, pp. 201-221). In this context, the important fact is that "each corporate reputation is unique and impossible to copy" (Marcellis-Warin and Teodoresco, 2012, p. 7), so each company has to work for its own good reputation.

According to Riahi-Belkaoui (2003, pp. 1-22), reputation explains relative market value for multinational firms. Moreover, the higher the corporate reputation, the greater is the impact of multinationality on the q-Value of the company.

In the studies on relationships between corporate reputation and financial variables, the proxies applied for corporate reputation were mainly points/numbers in rankings of companies with the best reputations (Black et al., 2000, pp. 31-42; Roberts and Dowling, 2002, pp. 1077-1093; Brammer et al., 2006, pp. 1-28; Smith et al., 2010, pp. 201-221; Cole, 2012, pp. 47-68; Blajer-Gołębiewska, 2014a, pp. 194-207 etc.). The most common is the list of America's Most Admired Companies, published by Fortune.

In the corporate reputation perspective, return on assets (ROA) is the most common proxy for financial performance (Black et al., 2000, pp. 31-42; Roberts and Dowling, 2002, pp. 1077-1093; Smith et al., 2010, pp. 201-221). Not only does it show a company's ability to generate profits, but it can also be used for comparisons across industries that are crucial while analysing companies from different sectors (Sabate and Puente, 2003, pp. 161-177). Similarly, a proxy for financial performance is sometimes a company's efficiency at generating profits from every unit of shareholder equity, which is represented by a return on equity indicator ROE (Smith et al., 2010, pp. 201-221; Blajer-Gołębiewska, 2014a, pp. 194-207). In their research, Smith and others (2010) used a wide range of financial indicators, which included cost of capital, volatility in sales, volatility net income, current ratio, and financial leverage. They found that companies with better reputations experienced superior financial performance and lower risk (measured as a lower cost of capital, less volatility in sales, and net income).

There were also other variables included in studies on corporate reputation, such as the size of a company (Black et al., 2000 pp. 31-42; Roberts and Dowling, 2002, pp. 1077-1093), relative market-to-book value (market value divided by total shareholder equity; Roberts and Dowling, 2002, pp. 1077-1093), stock price volatility (the standard deviation of the monthly logged price relatives; Hillier et al., 2008 Smith et al., 2010, pp. 201-221), and credit score - a measure calculated as the combination of main financial variables used also to predict bankruptcy and cost of debt issuances (Altman, 2000; Smith et al., 2010, pp. 201-221).

Studies on the value of corporate reputation show evidence of 'an invisible intangible asset that is value-relevant in explaining the market value of the firm' 
(Black et al., 2000, pp. 31-42). As mentioned above, it is often stated that corporate reputation is reflected in the relationship between a company's market value and its book value (Riahi-Belkaoui, 2003, pp. 1-22; Marcellis-Warin and Teodoresco, 2012, pp. 2-43). It may be also perceived as a representation of the validity of decisions on reputation-enhancing expenditures. Certainly, there is a gap between the book value of a company and its valuation by investors (market value). In the theory of business valuation, there are models aiming to calculate the value of corporate reputation on the basis of the gap.

There is a group of business valuation methods called the mixed methods, reputation-based methods, or goodwill-based methods. These include the Indirect Method, Direct Method (also called Anglo-Saxon Method), Union of European Accounting Experts Method (UEC Method), Risk-Bearind and Risk-Free Rate Method, and others. They are based on the assumption that a firm's real value consists of its book value and the value of its reputation/goodwill (Machała, 2011, pp. 506-508; Fernández, 2005, pp. 128-141). The value of reputation in these models is based on the difference between book value and other valuations. There is also a parameter that is explained differently in each of the mixed methods and represents the share of reputation in the difference between book value and the other valuations. In a basic approach, the parameter is assumed to be constant . In others, such as the UEC Method, the parameter is based on annuity calculation (Jaki, 2008, pp. 108-117). In the popular Gref Method, a discount rate and the amortization of reputation are also taken into consideration. There are also other mixed methods of different explanations of a parameter; in other words, explanations of a share of reputation is the excess of a company's market value over its book value (Jaki, 2008, pp. 108-117). Construction of the parameter is not the subject of this study, however; what is important is the idea that corporate reputation is related to the value of a company above its book value (above the net asset value).

Following the above-mentioned studies, it would be beneficial for understanding the problem of corporate reputation to identify financial determinants influencing investors' decisions to buy shares of a company and to place a certain value on a share that, very often, is higher than its results from book value. Therefore, in this study, the impact of financial determinants on corporate reputation, measured as a difference between its book value and market value, was analysed.

\section{Methods of the research}

In order to find an impact of financial variables on the perceived corporate reputation, the following stages of research were conducted: (1) selection of proxy for corporate reputation; (2) selection of proxies for a company's 
financial performance; (3) sectors and firms selection; (4) statistical analyses of panel data.

In this research, the impact is put on investors and their perception of corporate reputation as a result of a belief that a company is able to generate profits in the future. As a result, the chosen proxy for reputation is the difference between a firm's valuation by investors in the stock market (reflected in share prices and capitalization) and the value of a company's assets (book value). In order to achieve a comparable measure, a relative indicator was applied which is the MV to $\mathrm{BV}$ ratio.

This choice of proxy for corporate reputation is also driven by the lack of reputational rankings for most Polish companies. For example, in the Responsible Company ranking, the number of firms included is higher each year, but it reached only 72 firms in 2015 .

While considering financial determinants that could influence corporate reputation, we took into consideration literature analyses and the availability of data. As a result, three groups of variables were selected, representing:

- profitability: net profit, ROA, ROE, earnings per share;

- stability/size of a company: assets, equity, book value per share;

- level of risk: financial leverage, debt to assets, debt to equity, long-term liabilities, short-term liabilities.

We analysed the impact of selected financial variables and indicators on differences in the valuation of selected companies listed on the Warsaw Stock Exchange. Particularly, we analysed companies operating in the construction and IT sectors. These sectors were chosen for three reasons. Firstly, they represent different types of activities (industry vs. services), which impacts the diversity in the structure of their financial statements. Secondly, the sectors are suitable for data analysis, because each of them encompasses a relatively high number of companies, and there is a stock index for the sector. Lastly, the homogeneity of companies is relatively higher than in other sectors in their groups, which should enhance the stability of the estimated models. Initially, there were 35 companies listed in the construction sector and 36 IT companies. Some companies were excluded in the data-collecting process due to being in liquidation processes, which results in equivocal changes in financial indicators.

Finally, the data pertains to 62 companies: 27 listed in the construction sector and 35 IT companies. The time range spans from the first quarter of 2009 to the fourth quarter of 2015 , which gives us a maximum of 28 quarterly observations. Not every company included in the data set was listed on the stock exchange from the first period of our analysis, resulting in unbalanced panel data. The basic information about the size of the panel data was included in Table 1. 
Table 1

Size of the panel data

\begin{tabular}{|l|c|c|c|}
\hline \multicolumn{1}{|c|}{ Statistics } & Overall & $\begin{array}{c}\text { Construc- } \\
\text { tion sector }\end{array}$ & $\begin{array}{c}\text { IT } \\
\text { sector }\end{array}$ \\
\hline Number of observations & 1512 & 670 & 842 \\
\hline Length of time series & $13-26$ & $16-26$ & $13-26$ \\
\hline Number of companies & 62 & 27 & 35 \\
\hline
\end{tabular}

Source: own compilation

Financial indicators are published after the period they concern; thus, their impact on market value is shifted over time. In the case of the analysed companies (listed on the Warsaw Stock Exchange), the quarterly and consolidated quarterly reports shall be submitted at the same time (on the date specified by the issuer, but no later than within 45 days after the end of the quarter to which it relates). However, a company is not obligated to submit quarterly reports for the second and fourth quarters of the financial year, so companies do it voluntarily, often while submitting half-yearly reports and reports considering the whole fiscal year (Rozporządzenie Ministra..., 2014).

It was not our intention to analyse the short-term impact of earnings announcement on share prices, and consequently on market valuation, as it usually considers a few days after the announcement and may be biased by short-term behavioural anomalies. In order to analyse the changes in corporate reputation, we needed to check the effect after a longer term, which allows us to omit shortterm volatilities caused by the announcements.

As mentioned above, the impact of financial indicators on market value is shifted in time. To reflect this lag, we adjusted the Roberts and Dowling's model matching financial indicators from one quarter with the market value of the second quarter after the one in question (Fig. 2). Market value itself was computed as a product of mean share prices from a quarter and the number of shares. Due to the shifting, the maximum length of time series is 26.

The data about financial performance consists of observations from the same set of companies over multiple time periods. This is panel data, also known as longitudinal data.

The analysis was made so to reflect the intrinsic structure of the data. Therefore, the main focus of the analysis was on panel data models. Because of some features of the date described below, real values were replaced by various transformations. We have distinguished four approaches to the analysis: (1) multiple regression on ranks across time and companies; (2) multiple regression on ranks made separately for each period, (3) multiple regression on first differences; (4) analysis of contingency tables (chi-squared tests of independence and Yule's coefficient of colligation). 


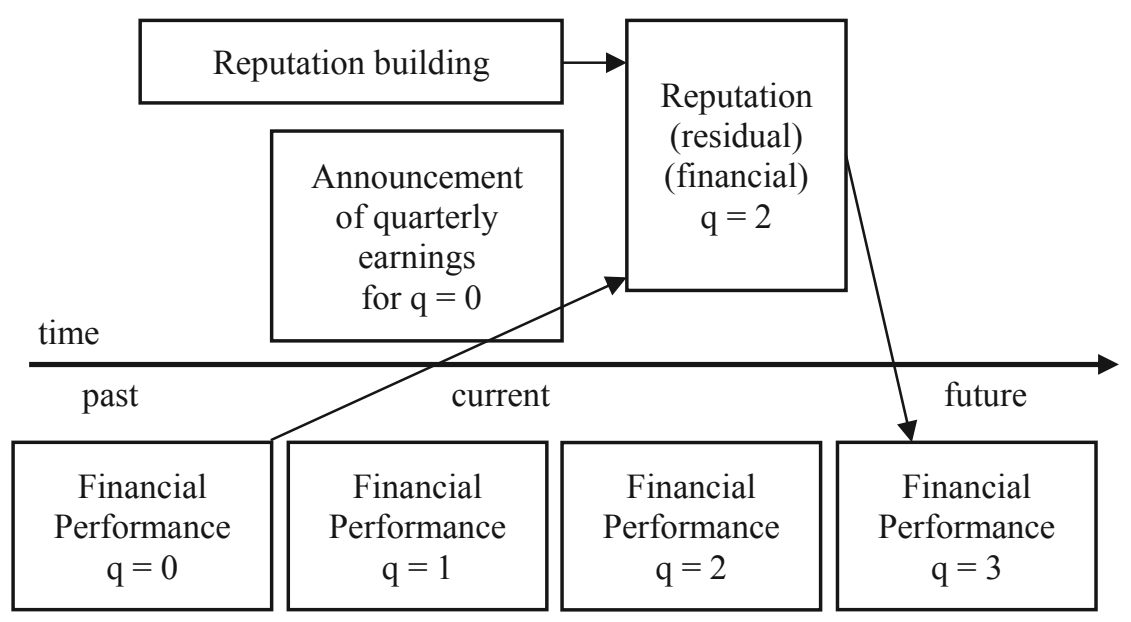

Figure 2. The applied stylization of the Roberts and Dowling model of reputation-financial dynamics (adjusted for quarterly observations) Source: own compilation on the basis of Roberts and Dowling (2002, p. 1078)

\section{Findings}

Overall, the data consists of 1512 unit observations, 670 belonging to the construction sector and 842 to the IT sector. Some basic descriptive statistics of the data set are shown in Table 2. All values with dimensions are expressed in thousands of PLN.

Table 2

Summary statistics of the data

\begin{tabular}{|l|l|c|c|c|c|c|c|}
\hline Variable & Sector & Min. & 1st Qu. & Median & Mean & 3rd Qu. & Max. \\
\hline \multirow{2}{*}{$\begin{array}{l}\text { Net } \\
\text { profit }\end{array}$} & constr. & -593000 & -266 & 1124 & 935 & 4491 & 190200 \\
\cline { 2 - 8 } & IT & -44890 & -55 & 516 & 4342 & 2575 & 241300 \\
\hline \multirow{2}{*}{ ROA } & constr. & -0.5184 & -0.0030 & 0.0059 & 0.0007 & 0.0162 & 0.1636 \\
\cline { 2 - 8 } & IT & -0.2763 & -0.0013 & 0.0086 & 0.0122 & 0.0225 & 0.4801 \\
\hline \multirow{2}{*}{ ROE } & constr. & -107.7000 & -0.0048 & 0.0118 & -0.2921 & 0.0335 & 0.5678 \\
\cline { 2 - 8 } & IT & -4.9110 & -0.0017 & 0.0126 & 0.0018 & 0.0318 & 0.6384 \\
\hline \multirow{2}{*}{$\begin{array}{l}\text { Earnings } \\
\text { per share }\end{array}$} & constr. & -26.9100 & -0.0119 & 0.0538 & 0.1547 & 0.3153 & 7.6150 \\
\cline { 2 - 8 } & IT & -3.7760 & -0.0041 & 0.0603 & 0.3548 & 0.2865 & 14.5200 \\
\hline
\end{tabular}


Financial determinants of corporate reputation: A short-term approach

Table 2 cont.

\begin{tabular}{|l|l|c|c|c|c|c|c|}
\hline \multirow{2}{*}{ Assets } & constr. & 7199 & 102300 & 242900 & 501700 & 523300 & 3859000 \\
\cline { 2 - 8 } & IT & 1304 & 26750 & 79720 & 313800 & 249300 & 5595000 \\
\hline \multirow{2}{*}{ Equity } & constr. & 427 & 55650 & 119900 & 172000 & 233700 & 1115000 \\
\cline { 2 - 8 } & IT & 396 & 16720 & 54980 & 246200 & 179200 & 5097000 \\
\hline \multirow{2}{*}{$\begin{array}{l}\text { Book } \\
\text { value per } \\
\text { share }\end{array}$} & constr. & 0.00 & 1.90 & 7.98 & 14.49 & 18.69 & 95.76 \\
\cline { 2 - 8 } & IT & 0.00 & 1.77 & 6.69 & 16.48 & 13.92 & 158.20 \\
\hline $\begin{array}{l}\text { Financial } \\
\text { leverage }\end{array}$ & constr. & 1.0640 & 1.4560 & 1.7890 & 9.3530 & 2.5760 & 2475.0000 \\
\hline \multirow{2}{*}{$\begin{array}{l}\text { Debt to } \\
\text { assets }\end{array}$} & constr. & 0.0601 & 0.3097 & 0.4404 & 0.4604 & 0.6097 & 0.9996 \\
\cline { 2 - 8 } & IT & 0.0046 & 0.1582 & 0.2724 & 0.3085 & 0.4349 & 0.9910 \\
\hline \multirow{2}{*}{$\begin{array}{l}\text { Debt to } \\
\text { equity }\end{array}$} & constr. & 0.0642 & 0.4495 & 0.7875 & 8.3400 & 1.5760 & 2474.0000 \\
\cline { 2 - 8 } & IT & 0.0046 & 0.1880 & 0.3785 & 0.9694 & 0.7840 & 109.5000 \\
\hline $\begin{array}{l}\text { Long- } \\
\text { term } \\
\text { liabilities }\end{array}$ & IT & 0 & 2565 & 11520 & 62280 & 62780 & 1222000 \\
\cline { 2 - 8 } & IT & 0.050 & 1.1960 & 1.3890 & 1.9710 & 1.7840 & 110.5000 \\
\hline $\begin{array}{l}\text { Short- } \\
\text { term } \\
\text { liabilities }\end{array}$ & constr. & 730 & 19870 & 66320 & 266400 & 187700 & 3075000 \\
\cline { 2 - 8 } & IT & 32 & 4823 & 14500 & 43890 & 53500 & 503400 \\
\hline $\begin{array}{l}\text { Market } \\
\text { value }\end{array}$ & constr. & 830 & 45850 & 138800 & 1745000 & 365100 & 109000000 \\
\cline { 2 - 8 } & IT & 635 & 17830 & 69330 & 419800 & 259800 & 25500000 \\
\hline $\begin{array}{l}\text { Market } \\
\text { value } / \\
\text { Equity }\end{array}$ & IT & 0.07 & 0.68 & 1.17 & 13.12 & 2.08 & 3705.00 \\
\cline { 2 - 8 } & IT & 0.08 & 0.65 & 1.07 & 6.78 & 2.19 & 965.90 \\
\hline
\end{tabular}

Source: own compilation

The most important feature of these empirical distributions is the presence of outliers. Almost every variable contains values that dramatically exceed the typical range of variability. Not only are minimal and maximal values far from average values, but also there are substantial differences between mean and median, indicating huge skewness, usually positive. For instance, the mean net profit for the IT sector is 4,302,000 PLN, while the median barely exceeds 500,000 PLN there are a few cases where net profit was much larger than the other ones, and they pull the mean far to the right on the axis.

Out of all of the companies in all time periods, corporate reputation, as defined above, was positive, i.e., the ratio of the market value to the book value was greater than one in 516 cases (34\%), of which, 193 concerned the construction sector and 323 concerned the IT sector. 
Because of the presence of outliers and, thus, considerable asymmetry in the variable distributions, parametric methods for analysing the data would be inappropriate. Although one can remove the outliers from the data and perform classical parametric analysis, the criteria for exclusion are always subjective to some extent. Therefore, we decided to keep all observations and (in order to minimize the impact of outliers) transform real values from a ratio or interval scale to an ordinal scale. The transformation was made in several different ways.

In the first approach, real values were replaced with their ranks across time and companies within a sector. A rank is the relative position of a value, if the data were sorted in an increasing way. With this solution, a company's performance is measured relative to its competitors' performance and to itself in different periods. The goal of the analysis was to model corporate reputation, defined as the ratio of $\mathrm{MV}$ to $\mathrm{BV}$ (the ratio is also ranked), against other variables. The first choice was to use multiple regression, considering the panel structure of the data. In the case of modelling panel data, two types of effects must be considered. One is the individual effect; i.e., the part of variability of the dependent variable that is specific to an individual (a company), causing a correlation in this individual's behaviour over time. Second is the time effect; i.e., the part of variability of the dependent variable that is specific to a time period, causing again a correlation in observations over the same period (Wooldridge, 2002, pp. 247-252). Each effect can be considered fixed (constant over time or across section) or random; i.e., as a realisation of a random variable with certain distribution. To test which approach is more suitable for each effect, the Hausman tests were performed (Hausman, 1978, pp. 1251-1271). The null hypothesis in the test states that the coefficients in both fixed and random effects models are consistent; but, the random effects model is preferred due to its higher efficiency. Under the alternative hypothesis, only a fixed effect estimator is consistent and, thus, preferred.

The other tests (which need to be done before choosing the final model) examine whether or not the individual and time effects are significant; otherwise, one can treat the data as homogeneous and fit the pooled model. These tests are the F test and Lagrange multiplier test (Breush and Pagan, 1980, pp. 239-253), for fixed and random effects, respectively.

The estimated fixed effects (two-way) model for the construction sector and the results for the accompanying tests are presented in Table 3 .

The results for the Hausman tests suggest that it is more appropriate to treat both individual and time effects as fixed. The F test for two-way effects (individual and time simultaneously) proves that both effects are significant. This means that companies, as well as time periods, have their own specific effects that are constant over time and across sections and affect the relationship between reputation and its regressors. 
Financial determinants of corporate reputation: A short-term approach

Table 3

Fixed effects (two-way) model for the construction sector

\begin{tabular}{|c|c|c|c|c|c|}
\hline Variable & Coefficient & \multirow{2}{*}{$\begin{array}{c}\text { Std. Err. } \\
0.0766\end{array}$} & t-value & \multicolumn{2}{|c|}{$\operatorname{Pr}(>|\mathbf{t}|)$} \\
\hline Net profit & -0.2219 & & -2.8974 & 0.0039 & $* *$ \\
\hline ROA & -0.3108 & 0.1216 & -2.5557 & 0.0108 & $*$ \\
\hline ROE & 0.4156 & 0.1408 & 2.9526 & 0.0033 & $* *$ \\
\hline Earnings per share & 0.1246 & 0.0664 & 1.8755 & 0.0612 & . \\
\hline Assets & -0.8375 & 0.1290 & -6.4901 & 0.0000 & $* * *$ \\
\hline Equity & 0.3828 & 0.0844 & 4.5359 & 0.0000 & $* * *$ \\
\hline Book value per share & -0.8526 & 0.0815 & -10.4557 & 0.0000 & $* * *$ \\
\hline Financial leverage & -0.8825 & 0.4847 & -1.8208 & 0.0691 & $*$ \\
\hline Debt to assets & 0.9870 & 0.7832 & 1.2602 & 0.2081 & \\
\hline Debt to equity & -0.1187 & 1.1676 & -0.1016 & 0.9191 & \\
\hline Long-term liabilities & 0.0813 & 0.0801 & 1.0148 & 0.3106 & \\
\hline Short-term liabilities & 0.3423 & 0.1455 & 2.3519 & 0.0190 & $*$ \\
\hline \multicolumn{6}{|c|}{ Signif. codes: 0 “***’ 0.001 “**’ 0.01 '*’ 0.05 '. 0.1 ‘, } \\
\hline \multicolumn{6}{|c|}{ R-Squared: $0.3050 \quad$ Adj. R-Squared: 0.2758} \\
\hline \multicolumn{6}{|c|}{ Hausman tests for panel model (random vs. fixed effects) } \\
\hline Effects & \multicolumn{2}{|c|}{ test statistics $\left(\chi^{2}\right)$} & df & \multicolumn{2}{|c|}{ p-value } \\
\hline individual & \multicolumn{2}{|l|}{67.42} & 12 & \multicolumn{2}{|c|}{0.0000} \\
\hline time & \multicolumn{2}{|c|}{\begin{tabular}{l|l}
133.03 & \\
\end{tabular}} & 12 & \multicolumn{2}{|c|}{0.0000} \\
\hline \multicolumn{6}{|c|}{ F test for two-way effects (fixed) } \\
\hline $\mathbf{F}$ & \multicolumn{2}{|l|}{ df1 } & df2 & \multicolumn{2}{|c|}{ p-value } \\
\hline 21.15 & \multicolumn{2}{|l|}{51} & 606 & \multicolumn{2}{|c|}{0.0000} \\
\hline
\end{tabular}

Source: own compilation

Since each value is replaced by rank, interpretation of the coefficients in terms of nominal impact of certain variables on the dependent variable is not possible. However, thanks to ranks, each variable is expressed on the same scale; thus, estimated coefficients allow for the comparison of the magnitude and direction of impact for each variable. The highest impact on reputation occurred in the cases of book value per share and assets, both variables being negatively correlated with reputation. Among other variables that are significant (i.e., with p-value less than 0.05 ) are net profit, ROA, ROE, equity, and financial leverage. However, the model is not well-fitted to the data; the adjusted $R^{2}$ is 0.28 , which is very low. 
The same procedure was done with the IT sector as with the construction sector. This time, Hausman tests suggested that the random effects model would be more suitable for individual effects and the fixed effect model would be more suitable for time effects. The F test indicated, however, that the time effect is not significant. This means that, unlike the construction sector, the IT sector could be perceived as homogenous over time. Nevertheless, each company has a somehow different relationship between reputation and financial indicators due to strong individual effects. Therefore, the random effects (individual) model was fitted to the data from the IT sector. The estimated model is presented in Table 4.

In the model above, four variables turned out to be significant: equity, book value per share, long-term liabilities, and financial leverage. The greatest impact on reputation has book value per share (negative), same as in the construction sector. The financial leverage, which was significantly positively correlated with reputation in the construction sector, is also significant in the IT sector, but its correlation is negative. Again, interpretation of the coefficient is to be done with caution, because the model is not well-fitted to the data (adjusted $\mathrm{R}^{2}=0.2769$ ).

Table 4

Random effects (individual) model for the IT sector

\begin{tabular}{|c|c|c|c|c|c|}
\hline Variable & Coefficient & Std. Err. & t-value & \multicolumn{2}{|c|}{$\operatorname{Pr}(>|t|)$} \\
\hline (Intercept) & 632.9484 & 42.6315 & 14.8470 & 0.0000 & $* * *$ \\
\hline Net profit & 0.0136 & 0.0563 & 0.2417 & 0.8091 & \\
\hline ROA & -0.0364 & 0.1295 & -0.2810 & 0.7788 & \\
\hline ROE & 0.0419 & 0.1258 & 0.3334 & 0.7389 & \\
\hline Earnings per share & 0.0787 & 0.0611 & 1.2889 & 0.1978 & \\
\hline Assets & 0.0773 & 0.1642 & 0.4706 & 0.6380 & \\
\hline Equity & 0.4615 & 0.1379 & 3.3465 & 0.0009 & $* * *$ \\
\hline Book value per share & -0.9107 & 0.0603 & -15.0983 & 0.0000 & $* * *$ \\
\hline Financial leverage & -0.1902 & 0.3152 & -0.6033 & 0.5465 & \\
\hline Debt to assets & 0.1425 & 0.8086 & 0.1762 & 0.8602 & \\
\hline Debt to equity & 0.2921 & 1.0650 & 0.2743 & 0.7840 & \\
\hline Long-term liabilities & -0.1500 & 0.0453 & -3.3149 & 0.0010 & $* * *$ \\
\hline Short-term liabilities & -0.3080 & 0.0672 & -4.5806 & 0.0000 & $* * *$ \\
\hline \multicolumn{6}{|c|}{ Signif. codes: 0 ‘***’ 0.001 “**’ 0.01 ‘*’ 0.05 '? 0.1 “' } \\
\hline \multicolumn{6}{|c|}{ R-Squared: 0.2812 Adj. R-Squared: 0.2769} \\
\hline
\end{tabular}


Financial determinants of corporate reputation: A short-term approach

Table 4 cont

\begin{tabular}{|l|c|c|c|}
\hline \multicolumn{4}{|c|}{ Hausman tests for panel model (random vs. fixed effects) } \\
\hline \multicolumn{1}{|c|}{ effects } & test statistics $\left(\chi^{2}\right)$ & df & p-value \\
\hline individual & 0.07 & 12 & 1.0000 \\
\hline time & 27.6 & 12 & 0.0063 \\
\hline \multicolumn{1}{|c|}{ Tests for individual and time effects } \\
\hline \multicolumn{1}{|c|}{ test } & test statistics & df & p-value \\
\hline $\begin{array}{l}\text { individual - random } \\
\text { (Lagrange multiplier test, } \\
\text { Breush-Pagan) }\end{array}$ & $\chi^{2}=4632.5$ & 1 & 0.0000 \\
\hline \begin{tabular}{l} 
time - fixed (F test) \\
\hline
\end{tabular} & $\mathrm{F}=1.25$ & $\begin{array}{l}\text { df1 }=25, \\
\text { df2 }=804\end{array}$ & 0.1857 \\
\hline
\end{tabular}

Source: own compilation

The second approach to the analysis consisted in replacing real values with ranks, similar to the first approach; but this time, the ranks have been made separately for each period. This means that, for each quarter, companies have been sorted by every variable, and ranks have been assigned ranging from one to a number of companies. The same panel data models as in the first approach were tested for each sector. The results of these analyses are shown in Tables 5 and 6.

Table 5

Fixed effects (individual) model for the construction sector (second approach)

\begin{tabular}{|l|c|c|c|c|c|}
\hline \multicolumn{1}{|c|}{ Variable } & Coefficient & Std. Err. & t-value & \multicolumn{2}{c|}{$\operatorname{Pr}(>|\mathbf{t}|)$} \\
\hline Net profit & -0.1651 & 0.0726 & -2.2749 & 0.0232 & $*$ \\
\hline ROA & -0.2297 & 0.0970 & -2.3682 & 0.0182 & $*$ \\
\hline ROE & 0.2925 & 0.1094 & 2.6730 & 0.0077 & $* *$ \\
\hline Earnings per share & 0.1219 & 0.0693 & 1.7595 & 0.0790 & $*$ \\
\hline Assets & -0.8444 & 0.1388 & -6.0816 & 0.0000 & $* * *$ \\
\hline Equity & 0.3960 & 0.0865 & 4.5778 & 0.0000 & $* * *$ \\
\hline Book value per share & -0.5496 & 0.0853 & -6.4456 & 0.0000 & $* * *$ \\
\hline Financial leverage & -0.4533 & 0.3676 & -1.2332 & 0.2180 & \\
\hline Debt to assets & 0.0300 & 0.4897 & 0.0613 & 0.9512 & \\
\hline Debt to equity & 0.5203 & 0.6786 & 0.7668 & 0.4435 & \\
\hline
\end{tabular}


Table 5 cont.

\begin{tabular}{|c|c|c|c|c|c|c|}
\hline Variable & Coefficient & \multirow{2}{*}{\multicolumn{2}{|c|}{$\begin{array}{c}\text { Std. Err. } \\
0.0899\end{array}$}} & t-value & \multicolumn{2}{|c|}{$\operatorname{Pr}(>|\mathbf{t}|)$} \\
\hline Long-term liabilities & -0.0364 & & & -0.4043 & 0.6861 & \\
\hline Short-term liabilities & 0.3772 & & 1362 & 2.7706 & 0.0058 & $* *$ \\
\hline \multicolumn{7}{|c|}{ Signif. codes: 0 ‘***’ 0.001 ‘**’ 0.01 ‘*’ 0.05 ‘’ 0.1 ‘ } \\
\hline \multicolumn{7}{|c|}{ R-Squared: 0.1569 Adj. R-Squared: 0.1478} \\
\hline \multicolumn{7}{|c|}{ Hausman tests for panel model (random vs. fixed effects) } \\
\hline Effects & \multicolumn{2}{|c|}{ test statistics $\left(\chi^{2}\right)$} & & df & \multicolumn{2}{|c|}{ p-value } \\
\hline individual & \multicolumn{2}{|l|}{108.55} & & 12 & \multicolumn{2}{|c|}{0.0000} \\
\hline \multicolumn{7}{|c|}{ F test for individual effects } \\
\hline $\mathbf{F}$ & \multicolumn{2}{|l|}{ df1 } & & df 2 & \multicolumn{2}{|c|}{ p-value } \\
\hline 20.29 & \multicolumn{2}{|l|}{26} & & 631 & \multicolumn{2}{|c|}{0.0000} \\
\hline
\end{tabular}

Source: own compilation

Table 6

Fixed effects (individual) model for IT sector (second approach)

\begin{tabular}{|c|c|c|c|c|c|}
\hline Variable & Coefficient & Std. Err. & t-value & \multicolumn{2}{|c|}{$\operatorname{Pr}(>|\mathbf{t}|)$} \\
\hline Net profit & 0.0114 & 0.0513 & 0.2218 & 0.8246 & \\
\hline ROA & 0.0280 & 0.1023 & 0.2733 & 0.7847 & \\
\hline ROE & -0.0019 & 0.0993 & -0.0188 & 0.9850 & \\
\hline Earnings per share & 0.0580 & 0.0565 & 1.0278 & 0.3044 & \\
\hline Assets & 0.1789 & 0.1396 & 1.2817 & 0.2003 & \\
\hline Equity & 0.4194 & 0.1177 & 3.5645 & 0.0004 & $* * *$ \\
\hline Book value per share & -0.6759 & 0.0584 & -11.5759 & 0.0000 & $* * *$ \\
\hline Financial leverage & -0.0027 & 0.2065 & -0.0131 & 0.9895 & \\
\hline Debt to assets & 0.1049 & 0.4059 & 0.2585 & 0.7961 & \\
\hline Debt to equity & 0.2405 & 0.5182 & 0.4641 & 0.6427 & \\
\hline Long-term liabilities & -0.1718 & 0.0445 & -3.8632 & 0.0001 & $* * *$ \\
\hline Short-term liabilities & -0.2931 & 0.0628 & -4.6670 & 0.0000 & $* * *$ \\
\hline \multicolumn{6}{|c|}{ Signif. codes: 0 “***’ 0.001 “**’ 0.01 '*’ 0.05 '? 0.1 ‘, } \\
\hline R-Squared: 0.1945 & -Squared: & & & & \\
\hline
\end{tabular}


Table 6 cont.

\begin{tabular}{|c|c|c|c|}
\hline \multicolumn{5}{|c|}{ Hausman tests for panel model (random vs. fixed effects) } \\
\hline effects & test statistics $\left(\chi^{2}\right)$ & df & p-value \\
\hline individual & 37.03 & 12 & 0.0002 \\
\hline \multicolumn{5}{|c|}{ F test for individual effects } \\
\hline F & df1 & df2 & p-value \\
\hline 40.38 & 34 & 795 & 0.0000 \\
\hline
\end{tabular}

Source: own compilation

Because of the way the data has been ranked, there is no point in taking time effects into consideration. Therefore, one Hausman test has been made for individual effects only. It indicated that the fixed effects model would be more appropriate. The $\mathrm{F}$ test strongly suggested that individual effects are significant. The fitted model has more or less the same estimated coefficients as the corresponding one from the first approach to data transformation. The same variables are significant and with the same direction. However, the model is poorly fitted to the data; the adjusted $\mathrm{R}^{2}$ do not exceed 0.15 .

The fixed effects (individual) model for the IT sector in the second approach shares the same characteristics as the random effects (individual) model in the first approach to data transformation (Tables 4 and 6). It has the same four significant variables with the same signs of coefficients. However, this model is weaker due to the lower $\mathrm{R}^{2}$.

In the third approach to modelling reputation, the first difference of real values were used instead of any transformation changing scale. The motivation of this operation was the assumption that investors tend to invest in companies that are able to improve their financial positions in terms of profitability, stability, and to lower their levels of risk. These positive changes could influence investors' decisions more than just single numbers. For instance, a higher profit in a given quarter does not guarantee a company's better performances in the future. A natural consequence of the introduction of differences is that the time dimension of data becomes shorter. Here, the length of data set became shorter by the number of companies.

The same procedure as previous was applied to fitting panel data models. For the construction sector, Hausman tests suggested using the random effects approach for both effects. The Lagrange multiplier tests proved only the individual effects to be significant. Therefore, the random effects (individual) model has been fitted, and the estimates are presented in Table 7.

Again, the model is not well-fitted to the data. Also, the differences are expressed in the units of variables; thus, the above-mentioned influence of outliers might be substantial. As a consequence, the estimated coefficients for the models presented in Tables 7 and 8 are unreliable. 
Anna Blajer-Gołębiewska, Arkadiusz Kozłowski

Table 7

Random effects (individual) model for the construction sector (third approach)

\begin{tabular}{|c|c|c|c|c|c|c|}
\hline \multirow{2}{*}{$\begin{aligned} \text { Variable } \\
\text { (Intercept) }\end{aligned}$} & \multirow{2}{*}{$\begin{array}{c}\text { Coefficient } \\
-1.1031 \\
\end{array}$} & \multirow{2}{*}{\multicolumn{2}{|c|}{$\begin{array}{c}\text { Std. Err. } \\
4.2695\end{array}$}} & \multirow{2}{*}{$\begin{array}{c}\text { t-value } \\
-0.2584 \\
\end{array}$} & \multicolumn{2}{|c|}{$\operatorname{Pr}(>|\mathbf{t}|)$} \\
\hline & & & & & 0.7962 & \\
\hline Net profit & 0.0016 & & 0002 & 6.8389 & 0.0000 & $* * *$ \\
\hline ROA & 8.8470 & & .8367 & 0.0611 & 0.9513 & \\
\hline ROE & 12.1070 & & 2716 & 3.7007 & 0.0002 & $* * *$ \\
\hline Earnings per share & -12.7691 & & 2771 & -2.9855 & 0.0029 & $* *$ \\
\hline Assets & -0.0003 & & 0030 & -0.0977 & 0.9222 & \\
\hline Equity & -0.0001 & & 0030 & -0.0347 & 0.9723 & \\
\hline Book value per share & -0.2578 & & 3082 & -0.1117 & 0.9111 & \\
\hline Financial leverage & 100.8556 & & .5211 & 0.2902 & 0.7717 & \\
\hline Debt to assets & -33.7633 & & 9449 & -0.3594 & 0.7194 & \\
\hline Debt to equity & -100.3062 & & .5238 & -0.2886 & 0.7730 & \\
\hline Long-term liabilities & 0.0008 & & 0030 & 0.2681 & 0.7887 & \\
\hline Short-term liabilities & 0.0001 & & 0030 & 0.0386 & 0.9692 & \\
\hline \multicolumn{7}{|c|}{ Signif. codes: 0 ‘***’ 0.001 ‘**’ 0.01 ‘*’ 0.05 ‘’ 0.1 ‘, } \\
\hline \multicolumn{7}{|c|}{ R-Squared: 0.2556 Adj. R-Squared: 0.2505} \\
\hline \multicolumn{7}{|c|}{ Hausman tests for panel model (random vs. fixed effects) } \\
\hline effects & \multicolumn{3}{|c|}{ test statistics $\left(\chi^{2}\right)$} & If & \multicolumn{2}{|c|}{ p-value } \\
\hline individual & \multicolumn{3}{|l|}{1.91} & 2 & \multicolumn{2}{|c|}{0.9995} \\
\hline time & \multicolumn{2}{|l|}{4.6} & \multicolumn{2}{|c|}{12} & \multicolumn{2}{|c|}{0.9701} \\
\hline \multicolumn{7}{|c|}{ Lagrange multiplier (Breush-Pagan) tests for individual and time effects } \\
\hline effects & \multicolumn{2}{|l|}{$\chi^{2}$} & \multicolumn{2}{|c|}{ df } & \multicolumn{2}{|c|}{ p-value } \\
\hline individual - random & \multicolumn{2}{|l|}{12.29} & \multicolumn{2}{|c|}{1} & \multicolumn{2}{|c|}{0.0005} \\
\hline time - random & \multicolumn{2}{|l|}{0.07} & \multicolumn{2}{|c|}{1} & \multicolumn{2}{|c|}{0.7914} \\
\hline
\end{tabular}

Source: own compilation

Another approach to the analysis could be the use of ranks of first differences. This approach was tested by the authors, and the results are very poor $\left(R^{2}\right.$ less than 0.05); therefore, they will not be presented in this paper. 
Financial determinants of corporate reputation: A short-term approach

Table 8

Random effects (individual) model for the IT sector (third approach)

\begin{tabular}{|c|c|c|c|c|c|c|}
\hline Variable & Coefficient & \multirow{2}{*}{\multicolumn{2}{|c|}{$\begin{array}{c}\text { Std. Error } \\
0.6860\end{array}$}} & t-value & \multicolumn{2}{|c|}{$\operatorname{Pr}(>|\mathbf{t}|)$} \\
\hline (Intercept) & -0.3316 & & & -0.4835 & 0.6289 & \\
\hline Net profit & 0.0000 & \multicolumn{2}{|c|}{0.0001} & 0.3660 & 0.7144 & \\
\hline ROA & -121.3203 & \multicolumn{2}{|c|}{30.2496} & -4.0106 & 0.0001 & $* * *$ \\
\hline ROE & 54.2505 & \multicolumn{2}{|c|}{5.2296} & 10.3737 & 0.0000 & $* * *$ \\
\hline Earnings per share & 0.5539 & \multicolumn{2}{|c|}{1.2823} & 0.4320 & 0.6659 & \\
\hline Assets & 0.0000 & \multicolumn{2}{|c|}{0.0002} & 0.1186 & 0.9057 & \\
\hline Equity & 0.0001 & \multicolumn{2}{|c|}{0.0002} & 0.3641 & 0.7159 & \\
\hline Book value per share & -0.3385 & \multicolumn{2}{|c|}{0.6944} & -0.4874 & 0.6261 & \\
\hline Financial leverage & 13.6253 & \multicolumn{2}{|c|}{16.2168} & 0.8402 & 0.4011 & \\
\hline Debt to assets & 54.3012 & \multicolumn{2}{|c|}{18.0786} & 3.0036 & 0.0028 & $* *$ \\
\hline Debt to equity & -17.4093 & \multicolumn{2}{|c|}{16.2219} & -1.0732 & 0.2835 & \\
\hline Long-term liabilities & 0.0000 & \multicolumn{2}{|c|}{0.0002} & -0.0926 & 0.9262 & \\
\hline Short-term liabilities & -0.0001 & \multicolumn{2}{|c|}{0.0002} & -0.3704 & 0.7112 & \\
\hline \multicolumn{7}{|c|}{ Signif. codes: 0 ‘***’ 0.001 ‘**’ 0.01 ‘*’ 0.05 ‘’ 0.1 ‘, } \\
\hline \multicolumn{7}{|c|}{ R-Squared: 0.2809 Adj. R-Squared: 0.2764} \\
\hline \multicolumn{7}{|c|}{ Hausman tests for panel model (random vs. fixed effects) } \\
\hline effects & \multicolumn{3}{|c|}{ test statistics $\left(\chi^{2}\right)$} & df & \multicolumn{2}{|c|}{ p-value } \\
\hline individual & \multicolumn{3}{|c|}{6.1} & 2 & \multicolumn{2}{|c|}{0.9109} \\
\hline time & \multicolumn{3}{|l|}{15.76} & 2 & \multicolumn{2}{|c|}{0.2026} \\
\hline \multicolumn{7}{|c|}{ Lagrange multiplier (Breush-Pagan) tests for individual and time effects } \\
\hline effects & \multicolumn{3}{|c|}{\begin{tabular}{l|l}
$\chi^{2}$ & \\
\end{tabular}} & df & \multicolumn{2}{|c|}{ p-value } \\
\hline individual - random & \multicolumn{2}{|l|}{16.1} & & 1 & \multicolumn{2}{|c|}{0.0001} \\
\hline time - random & \multicolumn{2}{|l|}{0.03} & & 1 & \multicolumn{2}{|c|}{0.8738} \\
\hline
\end{tabular}

Source: own compilation

The last approach to the analysis was to compare companies with positive reputations (i.e., where market value is greater than book value) to companies with negative reputations. Because of the presence of outliers and highly skewed distributions, the comparison was based on counts, and well-known chi-squared tests for independence were performed. Each variable was divided in half by median, and $2 \times 2$ contingency tables were created. To assess the magnitude of correlation, Yule's coefficients of colligation were also computed. The results of these computations are presented in Tables 9 and 10. 
Table 9

Chi-squared independence tests for the construction sector

\begin{tabular}{|c|c|c|c|c|c|c|}
\hline \multirow{2}{*}{\multicolumn{2}{|c|}{ Variable }} & \multicolumn{2}{|c|}{ Reputation } & \multirow{4}{*}{$\frac{\chi^{2}}{2.70}$} & \multirow{4}{*}{$\begin{array}{c}\text { p-value } \\
0.1003\end{array}$} & \multirow{4}{*}{$\begin{array}{c}\phi \\
0.067\end{array}$} \\
\hline & & \multirow{2}{*}{$\begin{array}{c}\text { MV }<\text { BV } \\
152\end{array}$} & \multirow{2}{*}{$\frac{\mathrm{MV}>\mathrm{BV}}{183}$} & & & \\
\hline \multirow{2}{*}{ Net profit } & $\mathrm{bm}$ & & & & & \\
\hline & $\mathrm{am}$ & 130 & 205 & & & \\
\hline \multirow{2}{*}{ ROA } & $\mathrm{bm}$ & 155 & 180 & \multirow{2}{*}{4.46} & \multirow{2}{*}{0.0346} & \multirow{2}{*}{0.085} \\
\hline & am & 127 & 208 & & & \\
\hline \multirow{2}{*}{ ROE } & $\mathrm{bm}$ & 162 & 173 & \multirow{2}{*}{10.29} & \multirow{2}{*}{0.0013} & \multirow{2}{*}{0.127} \\
\hline & $\mathrm{am}$ & 120 & 215 & & & \\
\hline \multirow{2}{*}{$\begin{array}{l}\text { Earnings } \\
\text { per share }\end{array}$} & $\mathrm{bm}$ & 133 & 202 & \multirow{2}{*}{1.38} & \multirow{2}{*}{0.2405} & \multirow{2}{*}{-0.048} \\
\hline & $\mathrm{am}$ & 149 & 186 & & & \\
\hline \multirow{2}{*}{ Assets } & $\mathrm{bm}$ & 174 & 161 & \multirow{2}{*}{25.87} & \multirow{2}{*}{0.0000} & \multirow{2}{*}{0.200} \\
\hline & am & 108 & 227 & & & \\
\hline \multirow{2}{*}{ Equity } & $\mathrm{bm}$ & 164 & 171 & \multirow{2}{*}{12.40} & \multirow{2}{*}{0.0004} & \multirow{2}{*}{0.139} \\
\hline & $\mathrm{am}$ & 118 & 217 & & & \\
\hline \multirow{2}{*}{$\begin{array}{l}\text { Book value } \\
\text { per share }\end{array}$} & $\mathrm{bm}$ & 108 & 227 & \multirow{2}{*}{25.87} & \multirow{2}{*}{0.0000} & \multirow{2}{*}{-0.200} \\
\hline & $\mathrm{am}$ & 174 & 161 & & & \\
\hline \multirow{2}{*}{$\begin{array}{l}\text { Financial } \\
\text { leverage }\end{array}$} & $\mathrm{bm}$ & 172 & 163 & 2070 & 00000 & 0.187 \\
\hline & $\mathrm{am}$ & 110 & 225 & 22.19 & 0.0000 & $0.18 /$ \\
\hline Doht to occot & $\mathrm{bm}$ & 173 & 162 & 2420 & 00000 & 0.102 \\
\hline DeDt to assets & $\mathrm{am}$ & 109 & 226 & 24.50 & 0.0000 & 0.195 \\
\hline & bm & 173 & 162 & & & \\
\hline Dedi to equity & am & 109 & 226 & 24.50 & 0.0000 & 0.193 \\
\hline Long-term & $\mathrm{bm}$ & 169 & 166 & 1852 & 00000 & 0160 \\
\hline liabilities & $\mathrm{am}$ & 113 & 222 & 10.52 & 0.0000 & 0.109 \\
\hline Short-term & $\mathrm{bm}$ & 169 & 166 & 1852 & 00000 & 0.160 \\
\hline liabilities & am & 113 & 222 & 18.52 & 0.0000 & 0.109 \\
\hline
\end{tabular}

Source: own compilation

The results presented in Tables 9 and 10 show that being either above or below median for almost every variable is significantly associated with having a positive or negative reputation. Nevertheless, such outcomes partially result from relatively high counts, which make small percentage differences statisti- 
cally significant. Yule's coefficients, showing the scale of correlation irrespective of number of observations, are relatively low; i.e., not far from zero. In the case of the construction sector, the highest absolute value of Yule's coefficient is 0.2 for assets and -0.2 for book value per share. In the case of the IT sector, book value per share is even more negatively associated with reputation, with the coefficient's value of -0.424 .

Table 10

Chi-squared independence tests for the IT sector

\begin{tabular}{|c|c|c|c|c|c|c|}
\hline \multirow{2}{*}{\multicolumn{2}{|c|}{ Variable }} & \multicolumn{2}{|c|}{ Reputation } & \multirow{2}{*}{$\chi^{2}$} & \multirow{2}{*}{ p-value } & \multirow{2}{*}{$\phi$} \\
\hline & & \multirow{2}{*}{$\begin{array}{c}\text { MV }<\text { BV } \\
213\end{array}$} & \multirow{2}{*}{$\begin{array}{c}\text { MV }>\text { BV } \\
208\end{array}$} & & & \\
\hline \multirow{2}{*}{ Net profit } & $\mathrm{bm}$ & & & \multirow{2}{*}{4.01} & \multirow{2}{*}{0.0452} & \multirow{2}{*}{0.071} \\
\hline & am & 183 & 238 & & & \\
\hline \multirow{2}{*}{ ROA } & $\mathrm{bm}$ & 219 & 202 & \multirow{2}{*}{8.01} & \multirow{2}{*}{0.0046} & \multirow{2}{*}{0.100} \\
\hline & am & 177 & 244 & & & \\
\hline \multirow{2}{*}{ ROE } & $\mathrm{bm}$ & 229 & 192 & \multirow{2}{*}{17.74} & \multirow{2}{*}{0.0000} & \multirow{2}{*}{0.148} \\
\hline & $\mathrm{am}$ & 167 & 254 & & & \\
\hline \multirow{2}{*}{$\begin{array}{l}\text { Earnings } \\
\text { per share }\end{array}$} & $\mathrm{bm}$ & 195 & 226 & \multirow{2}{*}{0.12} & \multirow{2}{*}{0.7299} & \multirow{2}{*}{-0.014} \\
\hline & $\mathrm{am}$ & 201 & 220 & & & \\
\hline \multirow{2}{*}{ Assets } & $\mathrm{bm}$ & 177 & 244 & \multirow{2}{*}{8.01} & \multirow{2}{*}{0.0046} & \multirow{2}{*}{-0.100} \\
\hline & am & 219 & 202 & & & \\
\hline \multirow{2}{*}{ Equity } & $\mathrm{bm}$ & 175 & 246 & \multirow{2}{*}{9.65} & \multirow{2}{*}{0.0019} & \multirow{2}{*}{-0.109} \\
\hline & am & 221 & 200 & & & \\
\hline \multirow{2}{*}{$\begin{array}{l}\text { Book value } \\
\text { per share }\end{array}$} & $\mathrm{bm}$ & 109 & 312 & \multirow{2}{*}{149.36} & 00000 & -0424 \\
\hline & am & 287 & 134 & & 0.0000 & $-0.4<4$ \\
\hline Financial leveraoe & $\mathrm{bm}$ & 219 & 202 & 801 & 00046 & 0100 \\
\hline Financial reverage & $\mathrm{am}$ & 177 & 244 & 0.01 & 0.0040 & 0.100 \\
\hline Deht to ascets & $\mathrm{bm}$ & 218 & 203 & 725 & 00071 & 0095 \\
\hline DeDT to assets & am & 178 & 243 & 1.25 & $0.00 / 1$ & (2) \\
\hline Debt to equity & $\mathrm{bm}$ & 218 & 203 & 725 & 00071 & 0095 \\
\hline & am & 178 & 243 & & & \\
\hline Long-term & $\mathrm{bm}$ & 189 & 232 & 138 & 02405 & -0043 \\
\hline liabilities & am & 207 & 214 & 1.50 & $0.240)$ & -0.045 \\
\hline Short-term & $\mathrm{bm}$ & 185 & 236 & 298 & 00843 & -0062 \\
\hline liabilities & $\mathrm{am}$ & 211 & 210 & 2.90 & 0.0045 & -0.002 \\
\hline
\end{tabular}


Despite not being very high, Yule's coefficients of colligation are in line with most of the regression coefficients from the panel data models in the first and second approaches. In both sectors, book value per share seems to have the strongest influence on perceived reputation, and it is negative (which means the greater the book value per share, the smaller the reputation). Book value (equity) itself is positively correlated with reputation. Other than these two factors, there are more differences than similarities between the sectors. According to regression analysis, profitability has more impact on reputation in the construction sector, whereas it is irrelevant in the IT sector.

\section{Conclusions, study weaknesses, and directions for future research}

In the study, we wanted to verify short-term impacts of selected financial determinants on corporate reputation (as perceived by investors) in the context of Roberts and Dowling's model of reputation-financial performance dynamics. In the model, it is assumed that past financial performance influences reputation, and reputation influences future financial performance of a given company (Roberts and Dowling, 2002, pp. 1077-1093). As the influence of reputation on financial performance was widely investigated and presented within the literature, we wanted to focus on the other part of the model: financial determinants influencing corporate reputation.

In order to find an indicator for corporate reputation (as perceived by investors), we applied an approach from the field of business valuation assuming that corporate reputation is reflected in the gap between the book value of a company and the value that investors put on it (market value of a company).

Regarding quarter-to-quarter observations, analysed financial factors either weakly affect or do not affect corporate reputation. In both analysed sectors changes in profitability significantly affected corporate reputation. Nevertheless, it is clear that the two analysed sectors have somehow different relationships between financial determinants and corporate reputation. Generally, it seems that other determinants of corporate reputation in the construction sector are stability and profitability. For corporate reputation as perceived by investors in the IT sector, significant determinants are stability and the level of financial risk (measured with long- and short-term liabilities and changes in the debt-to-assets ratio).

The main weakness of the study is that the above findings are limited to the two examined sectors - the estimated relationships in the construction sector differ from those in the IT sector (and the same probably applies to other sectors). Also, the estimated models are not well-fitted to the data, which may mean 
either financial factors do not influence corporate reputation at all, or the type of relationships is different than examined.

The popular sentence says that reputation takes time to build up, but it is easily damaged (Scott and Walsham, 2005, pp. 308-322). Data analyses conducted for the purpose of this study seems to be consistent with this thesis. The fact that there are only weak influences of financial variables on corporate reputation could be explained by the fact that reputation building is a long process, taking place in many small steps.

Therefore, it is necessary to conduct a similar study taking into account the long-term impact of financial factors on the development of the reputation of stock listed companies. Moreover, it would be beneficial to conduct analyses of impacts of other factors that may influence corporate reputation, which constitute the residual reputation in Roberts and Dowling. Such analyses should be conducted not only in the long-run, but also in the short-run (for example, by applying an event study methodology).

\section{References}

[1] Altman, E.I. (2000) 'Predicting financial distress of companies: Revisiting the Z-score and ZETA models', Working Paper, Dept. of Finance, NYU, July 2000.

[2] Anderson, J. and Smith, G.N. (2006) 'A Great Company Can Be a Great Investment', Financial Analysts Journal, vol. 62, no. 4, pp. 86-93.

[3] Barnett, M.L., Jermier, J.M. and Lafferty, B.A. (2006) 'Corporate Reputation: The Definitional Landscape', Corporate Reputation Review, vol. 9, no. 1, pp. 26-38.

[4] Beatty, R.P. and Ritter, J.R. (1986) 'Investment Banking, Reputation, and Underpricing of Initial Public Offerings', Journal of Financial Economics, vol. 15, no. 1-2, pp. 213-232.

[5] Black E.L., Carnes, T.A. and Richardson, V.J. (2000) 'The Market Valuation of Corporate Reputation', Corporate Reputation Review, vol. 3, no. 1, pp. 31-42.

[6] Blajer-Gołębiewska, A. (2014a) 'Corporate Reputation and Economic Performance: the Evidence from Poland', Economics and Sociology, vol. 7, no. 3, pp. 194-207.

[7] Blajer-Gołębiewska, A. (2014b) 'Do Stock Exchange Indices Based on Reputational Factors Matter?', International Journal of Academic Research, Part B, vol. 6, no. 4, pp. 231-237.

[8] Blajer-Gołębiewska, A. and Kos, M. (2016) 'Investors are More Sensitive to Information About Financial Rather than Ethical Reputation of a Company: Evidence from an Experimental Study', Economics and Sociology, vol. 9, no. 1, pp. 11-31. 
[9] Brammer, S., Brooks, C. and Pavelin, S. (2006) 'Corporate Reputation and Stock Returns: Are Good Firms Good for Investors?', ICMA Center Discussion Papers in Finance, DP2006-05.

[10] Brennan, N.M., Guillamon-Saorin, E. and Pierce, A. (2009) 'Impression management: Developing and illustrating a scheme of analysis for narrative disclosures - A methodological note: Accounting', Auditing and Accountability Journal, vol. 22, no. 5, pp. 789-832.

[11] Breusch, T.S. and Pagan, A.R. (1980) 'The Lagrange multiplier test and its applications to model specification in econometrics', Review of Economic Studies, vol. 47, no. 1, pp. 239-253.

[12] Cole, S. (2012) 'The Impact of Reputation on Market Value', World Econom$i c s$, vol. 13 , no. 3, pp. 47-68.

[13] Cox, P., Brammer, S. and Millington, A. (2004) 'An Empirical Examination of Institutional Investor Preferences for Corporate Social Performance', Journal of Business Ethics, vol. 52, no. 1, pp. 27-43.

[14] Easton, P. and Harris, T. (1991) 'Earnings as an Explanatory Variable for Returns', Journal of Accounting Research, vol. 29, no. 1, pp. 19-36.

[15] Feltham, G.A. and Ohlson, J.A. (1995) 'Valuation and clean surplus accounting for operating and financial activities', Contemporary Accounting Research, vol. 11, no. 2, pp. 689-731.

[16] Fernández, P. (2005) 'Company Valuation Methods: The most common Errors in Valuation', Investment Management and Financial Innovations Journal, vol. 2, no. 2, pp. 128-141.

[17] Fombrun, C.J. and van Riel, C.B.M. (1997) 'The Reputational Landscape', Corporate Reputation Review, vol. 1, no. 1/2, pp. 5-13.

[18] Harrington, C. (2003) 'Socially Responsible Investing', Journal of Accountancy, January, pp. 52-61.

[19] Hausman, J.A. (1978) 'Specification tests in econometrics', Econometrica, vol. 46 , no. 6 , pp. 1251-1271.

[20] Hillier, D., Grinblatt, M. and Titman, S. (2008) Financial Markets and Corporate Strategy, New York: McGraw-Hill.

[21] Jaki, A. (2008) Wycena i kształtowanie wartości przedsiębiorstwa, Kraków: Oficyna Wolters Kluwer.

[22] Machała R. (2011) Zarządzanie finansami i wycena firmy, Wrocław: Wydawnictwo Unimex.

[23] Marcellis-Warin de, N. and Teodoresco, S. (2012) 'Corporate Reputation: Is Your Most Strategic Asset at Risk?', Center for Interuniversity Research and Analysis on Organizations, Burgundy Report 2012RB-01.

[24] Responsible Company Ranking (2015) Responsible Business Forum, [Online], Available: http://odpowiedzialnybiznes.pl [15 May 2016]. 
[25] Riahi-Belkaoui, A. (1999) 'Contextual Accrual and Cash Flow Based Valuation Models: Impact of Multinationality and Reputation', Advances in Financial Planning and Forecasting, vol. 10, pp. 25-36.

[26] Riahi-Belkaoui, A. (2003) 'Corporate Reputation, Internalization and the Market Valuation of Multinational Firms', Working paper, University of Illinois at Chicago, [Online], Available: http://ssrn.com/abstract $=412005$ [2 Jan 2016].

[27] Roberts, P. and Dowling, G. (2002) 'Corporate Reputation and Sustained Superior Financial Performance’, Strategic Management Journal, vol. 23, no. 12, pp. 1077-1093.

[28] Rozporządzenie Ministra Finansów w sprawie informacji bieżących i okresowych przekazywanych przez emitentów papierów wartościowych oraz warunków uznawania za równoważne informacji wymaganych przepisami prawa państwa niebędącego państwem członkowskim, Dz. U. 2014, poz. 133, [Online], Available: http://www.isip.sejm.gov.pl [17 May 2016].

[29] Sabate, J.M. and Puente, E. (2003) 'Empirical Analysis of the relationship between corporate reputation and financial performance: A survey of the literature', Corporate Reputation Review, vol. 6, no. 2, pp. 161-177.

[30] Scott, S.V. and Walsham, G. (2005) 'Reconceptualising and managing reputation risk in the knowledge economy: towards reputable action', Organizational Science, vol. 16, no. 3, pp. 308-322.

[31] Smith, K.T., Smith, M. and Wang, K. (2010) 'Does Brand Management of Corporate Reputation Translate into Higher Market Value?', Journal of Strategic Marketing, vol. 18, no. 3, pp. 201-221.

[32] Wooldridge, J.M. (2002) Econometric analysis of cross-section and panel data, London: MIT Press. 